\title{
MENGENAL SEJARAH KURIKULUM NASIONAL INDONESIA DAN HUBUNGANNYA TERHADAP PENGEMBANGAN KURIKULUM PENDIDIKAN AGAMA KRISTEN MASA KINI
}

Oleh: Ramses Simanjuntak, M.Pd.K

\begin{abstract}
If we look at the course of our national education curriculum then we see that the government has struggled to bring a curriculum that is in accordance with the context of learning Indonesian society, it is proven through research change of curriculum that has been going on 10 times.In an effort to understand the history of the national education curriculum mentioned above, the author tries to raise a topic that is closely related to the history of the curriculum and its relationship with the curriculum of Christian Education held in Christian theology / religion schools in remote areas of this country.
\end{abstract}

\begin{abstract}
Abstrak
Kalau kita melihat perjalanan kurikulum pendidikan nasional kita maka kita melihat bahwa pemerintah sudah berjuang keras untuk menghadirkan kurikulum yang sesuai dengan konteks belajar masyarakat Indonesia, itu terbukti melalui riset pergantian kurikulum yang sudah berlangsung sebanyak 10 kali. Dalam upaya memahami tentang sejarah kurikulum pendidikan nasional tersebut diatas, penulis mencoba mengangkat sebuah topik yang berkaitan erat dengan sejarah kurikulum dan hubungannya dengan kurikulum Pendidikan Agama Kristen yang dilaksanakan di sekolah-sekolah teologi/agama kristen di pelosok negeri ini.
\end{abstract}

Kurikulum, Sejarah Kurikulum, Pendidikan Agama Kristen (PAK), Guru PAK

\section{Pendahuluan}

Upaya untuk memperbaiki dan meningkatkan mutu pendidikan di negeri tercinta ini seakan tidak pernah berhenti, hal itu terlihat jelas dari kerja keras pemerintah di dalam menemukan model yang tepat dan terbaik bagi pendidikan di Indonesia. ${ }^{1}$ Kalau kita melihat perjalanan kurikulum pendidikan nasional kita maka kita melihat bahwa pemerintah sudah berjuang keras untuk menghadirkan kurikulum yang sesuai dengan konteks belajar

\footnotetext{
${ }^{1}$ Abdul Majid, Perencanaan Pembelajaran, Mengembangakan Standar Dan Kompetenssi Guru (Bandung: Penerbit PT Remaja Rosdakarya, 2011), 3
} 
masyarakat Indonesia, itu terbukti melalui riset pergantian kurikulum yang sudah berlangsung sebanyak 10 kali.

Dalam upaya memahami tentang sejarah kurikulum pendidikan nasional tersebut diatas, penulis mencoba mengangkat sebuah topik yang berkaitan erat dengan sejarah kurikulum dan hubungannya dengan kurikulum Pendidikan Agama Kristen yang dilaksanakan di sekolah-sekolah teologi/agama kristen di pelosok negeri ini.

Untuk itu, dalam penulisan jurnal yang berjudul "Mengenal Sejarah Kurikulum Nasional Indonesia Dan Hubungannya Terhadap Pengembangan Kurikulum PAK Masa Kini," maka penulis mencoba untuk mengetengahkan fakta-fakta yang valid dan aktual tentang sejarah kurikulum nasional dan hubungannya terhadap pengembangan kurikulum PAK masa kini. Kegunaan jurnal ini adalah berfaedah sebagai karya ilmiah untuk memberikan kontribusi bagi banyak orang, khususnya guru Kristen.

\section{Pengertian Kurikulum}

Kurikulum adalah sebuah istilah yang sering kita dengar dalam sebuah mata pelajaran atau di dalamsebuah prosespendidikan, bahkan tak jarang banyak orang menganggap bahwa kurikulum adalah urusan sekolah dan semua perangkat yang ada didalamnya. Agar tidak menjadi bias maka disini penulis mencoba untuk memberikan pengertian dan definisi dari kurikulum itu sesuai pendapat dari beberapa ahli.

Kerr, J.F mengatakan bahwa kurikulum adalah semua pembelajaran yang dirancang dan dilaksanakan secara individu ataupun berkelompok, baik disekolah maupun diluar sekolah. Sedangkan menurut Inlow, kurikulum adalah usaha menyeluruh yang dirancang khusus oleh pihak sekolah guna membimbing murid untuk memperoleh hasil dari pembelajaran yang sudah ditentukan. Menurut definisi Neagley dan Evanskurikulum adalah semua pengalaman yang telah dirancang oleh pihak sekolah. Menurut pendapat Beauchamp, pengertian kurikulum adalah dokumen tertulis yang kandungannya berisi mata pelajaran yang akan diajarkan kepada peserta didik dengan melalui berbagai mata pelajaran, pilihan disiplin ilmu, rumusan masalah dalam kehidupan sehari-hari. Pengertian kurikulum menurut definisi Good V.Carter,adalah kumpulan kursus ataupun urutan pembelajaran yang sistematik. Menurut UU No. 20 Tahun 2003, pengertian kurikulum adalah seperangkat rencana dan pengaturan mengenai tujuan, isi dan bahan pembelajaran serta cara yang digunakan sebagai pedoman penyelenggaraan kegiatan pembelajaran untuk mencapai tujuan pendidikan nasional. Dan menurut Murray Print kurikulum adalah sebuah ruang pembelajaran yang terencana, yang diberikan secara langsung kepada siswa oleh sebuah lembaga pendidikan dan pengalaman yang dapat dinikmati oleh semua siswa pada saat kurikulum diterapkan. $^{2}$

Kurikulum secara umum terbagi menjadi dua, yakni pandangan lama dan pandangan baru. Menurut pandangan lama, kurikulum adalah sejumlah mata pelajaran yang harus ditempuh murid untuk memperoleh ijazah. Sedangkan menurut pandangan baru, kurikulum adalah seperangkat rencana dan pengaturan mengenai tujuan, isi, dan bahan

${ }^{2}$ http://www.artikelsiana.com/pengertian-kurikulum-fungsi-komponen. Diakses tanggal 10 April 2016 
pelajaran serta cara yang digunakan sebagai pedoman penyelenggaraan kegiatan pembelajaran untuk mencapai tujuan pendidikan tertentu. ${ }^{3}$

Menurut Hilda Tabaialah suatu kurikulum biasanya mengandung suatu pernyataan mengenai maksud dan tujuan tertentu; ia memberi petunjuk tentang beberapa pilihan dan susunan isinya; didalamnya menyiratkan pola-pola belajar dan mengajar tertentu yang dikehendaki oleh tujuan dan isinya ${ }^{4}$.

Bagi seorang guru kurikulum berarti kumpulan silabus yang tercetak, uraian satu persatu mata pelajaran, disertai pengantar yang bersifat umum mengenai tujuan masingmasing mata pelajaran.Mungkin secara insidental dan ilustratif terdapat pokok mengenai metode mengajar dan sebagai guru yang professional diharapkan memahami semua maksud dan tujuan yang terdapat dalam pengantar.

Kurikulum aslinya berarti lapangan perlombaan yang harus dilalui oleh murid dan guru. Lazimnya dipahami orang sebagai bahan-bahan tercetak (buku, majalah) berisikan pelajaran, petunjuk-petunjuk, gambar-gambar, soal, dan sebagainya.

International Council of Religious Education mendefinisikan "Kurikulum PAK adalah pengalaman si pelajar dibawah bimbingan"5 jadi semua pengalaman murid dalam rumah tangga, gereja dan sekolah digunakan untuk mencapai tujuan pendidikan gereja.

Ada berbagai macam model kurikulum ${ }^{6}$, yakni: (1) Uniform Lesson (pelajaran seragam) bahan pelajaran yang sama ditujukan untuk semua umur ; (2) Group graded lesson (pelajaran yang disesuaikan dengan kelompok) bahan pelajaran berbeda ditujukan untuk kelompok umur yang berlainan ; (3) Closely graded lesson (pelajaran yang disesuaikan secara ketat) misalnya bahan pelajaran khusus utk 1 th saja ; (4) Pelajaran untuk PAK diluar gereja. Lazimnya berupa buku pegangan baik untuk guru maupun murid ; (5) Buku pelajaran untuk sekolah. Di Indonesia ditujukan untuk murid SD,SMP dan SMA yang diterbitkan oleh KOMPAK DGI ; (6) Bahan-bahan pelajaran lain :

Pertama, Berupa buku, majalah, brosur, atau manual berisikan topic-topik pendidikan untuk anggota-anggota gereja; dapat dibuat khusus untuk kaum pria, wanita, penginjilan atau buku utk katekisasi ; Kedua, berupa gambar-gambar, slide, alat peraga, majalah Kristen, film Kristen, dsb ; Ketiga, Jenis kurikulum yang lain, misalnya:Kurikulum denominasi. Yang diterbitkan oleh denominasi tertentu, untuk kalangan sendiri ; Kurikulum bukan denominasi. Penerbitnya bukan denominasi tapi komersial ; Kurikulum usaha bersama. Ini terbitan dari beberapa denominasi bersama- sama ; Kurikulum yang berpusatkan pada isi. (content center curriculum), Ini memusatkan pelajaran Alkitab, membahas bagian2 Alkitab satu persatu ; Kurikulum yang berpusatkan pada pengalaman (Experience-Centered curriculum). Isinya menitik beratkan pengalaman murid, lalu menghubungkannya dengan Alkitab dan iman Kristen ; Kurikulum berdasarkan unit (Unit of Study) Tujuannya adalah memberi pelajaran yang lebih luas, baik pengalaman atau pokok pelajaran.

\footnotetext{
2009), 3

${ }^{3}$ Oemar Hamalik. Dasar-Dasar Pengembangan Kurikulum (Bandung: Penerbit PT Remaja Rosdakarya,

${ }^{4}$ Hilda Taba. Curriculum development; theory and practice (New York : Harcourt, Brace \& World, 1962), 58

${ }^{5}$ International Council of Religious Education in Journal Religious Education The official journal of the Religious Education Association. (Volume 2, 2006), 51

${ }^{6}$ Yudha Nata Saputra, Diktat Pengembangan Kurikulum PAK, Semester VII STT Cipanas (CipanasJawa Barat, 2012). 5
} 


\section{Sejarah Perkembangan Kurikulum di Indonesia}

\section{Rencana Pelajaran $1947^{7}$}

Kurikulum pertama yang lahir pada masa kemerdekaan memakai istilah leer plan. Dalam bahasa Belanda, artinya rencana pelajaran, lebih popular dibandingkan dengan curriculum (bahasa Inggris). Perubahan kisi-kisi pendidikan lebih bersifat politis: dari orientasi pendidikan Belanda ke kepentingan nasional. Asas pendidikan ditetapkan Pancasila. Rencana Pelajaran 1947 baru dilaksanakan sekolah-sekolah pada 1950. Sejumlah kalangan menyebut sejarah perkembangan kurikulum diawali dari Kurikulum 1950. Bentuknya memuat dua hal pokok: daftar mata pelajaran dan jam pengajarannya, ditambah garis-garis besar pengajaran. Rencana Pelajaran 1947 mengurangi pendidikan pikiran. Hal yang diutamakan adalah pendidikan watak, kesadaran bernegara dan bermasyarakat, materi pelajaran dihubungkan dengan kejadian sehari-hari, perhatian terhadap kesenian dan pendidikan jasmani.

\section{Rencana Pelajaran Terurai $1952^{8}$}

Kurikulum ini lebih merinci setiap mata pelajaran yang disebut Rencana Pelajaran Terurai 1952. "Silabus mata pelajarannya jelas sekali. seorang guru mengajar satu mata pelajaran," kata Djauzak Ahmad, Direktur Pendidikan Dasar Depdiknas periode 1991-1995. Ketika itu, di usia 16 tahun Djauzak adalah guru SD Tambelan dan Tanjung Pinang, Riau. Di penghujung era Presiden Soekarno, muncul Rencana Pendidikan 1964 atau Kurikulum 1964. Fokusnya pada pengembangan daya cipta, rasa, karsa, karya, dan moral (Pancawardhana). Mata pelajaran diklasifikasikan dalam lima kelompok bidang studi: moral, kecerdasan, emosional/artistik, keprigelan (keterampilan), dan jasmaniah. Pendidikan dasar lebih menekankan pada pengetahuan dan kegiatan fungsional praktis.

\section{Rencana Kurikulum 1964 dan Kurikulum $1964^{9}$}

Bentuknya memuat 5 hal pokok berikut: a. Manusia Indonesia berjiwa Pancasila, b. ManPower, c. Kepribadian Kebudayaan Nasional yang luhur, d. Ilmu dan teknologi yang tinggi, dan e. Pergerakan rakyat dan revolusi.

Rencana Pendidikan 1964 melahirkan Kurikulum 1964 yang menitik beratkan pada pengembangan daya cipta, rasa, karsa, karya, dan moral, yang kemudian dikenal dengan istilah Pancawardhana.

\section{6.}

http://www.musbir.blogspot.com/kurikulum-yang-pernah-berlaku-di.html. Diakses tanggal 16 April

\footnotetext{
${ }^{8} \mathrm{Ibid}$

${ }^{9}$ http://www.musbir.blogspot.com/kurikulum-yang-pernah-berlaku-di.html. Diakses tanggal 16 April
} 


\section{Kurikulum 1968 10}

Kelahiran Kurikulum 1968 bersifat politis: mengganti Rencana Pendidikan 1964 yang dicitrakan sebagai produk Orde Lama. Tujuannya pada pembentukan manusia Pancasila sejati. Kurikulum 1968 menekankan pendekatan organisasi materi pelajaran: kelompok pembinaan Pancasila, pengetahuan dasar, dan kecakapan khusus. Jumlah pelajarannya 9.

Djauzak menyebut Kurikulum 1968 sebagai kurikulum bulat. "Hanya memuat mata pelajaran pokok-pokok saja," katanya. Muatan materi pelajaran bersifat teoritis, tak mengaitkan dengan permasalahan faktual di lapangan. Titik beratnya pada materi apa saja yang tepat diberikan kepada siswa di setiap jenjang pendidikan.

\section{Kelebihan Kurikulum 1968}

Pendidikan diarahkan pada kegiatan mempertinggi kecerdasan dan keterampilan, serta mengembangkan fisik yang sehat dan kuat

\section{Kekurangan Kurikulum 1968}

Hanya memuat mata pelajaran pokok saja dan muatan materi pelajaran bersifat teoritis, tidak mengaitkan dengan permasalahan faktual di lapangan.

\section{Kurikulum 1975 11}

Kurikulum 1975 menekankan pada tujuan, agar pendidikan lebih efisien dan efektif. "Yang melatarbelakangi adalah pengaruh konsep di bidang manejemen, yaitu MBO (management by objective) yang terkenal saat itu," kata Drs. Mudjito, Ak, MSi, Direktur Pembinaan TK dan SD Depdiknas. Metode, materi, dan tujuan pengajaran dirinci dalam Prosedur Pengembangan Sistem Instruksional (PPSI). Zaman ini dikenal istilah "satuan pelajaran", yaitu rencana pelajaran setiap satuan bahasan. Setiap satuan pelajaran dirinci lagi: petunjuk umum, tujuan instruksional khusus (TIK), materi pelajaran, alat pelajaran, kegiatan belajar-mengajar, dan evaluasi. Kurikulum 1975 banyak dikritik. Guru dibikin sibuk menulis rincian apa yang akan dicapai dari setiap kegiatan pembelajaran.

\footnotetext{
${ }^{10} \mathrm{Ibid}$

${ }^{11}$ http://www.musbir.blogspot.com/kurikulum-yang-pernah-berlaku-di.html. Diakses tanggal 16 April 


\section{Karakteristik kurikulum 1975}

Berorientasi pada tujuan; Menganut pendekatan integrative dalam arti bahwa setiap pelajaran memiliki arti dan peranan yang menunjang kepada tercapainya tujuan-tujuan yang lebih integratif ; Menekankan kepada efisiensi dan efektivitas dalam hal daya dan waktu ; Menganut pendekatan sistem instruksional yang dikenal dengan Prosedur Pengembangan Sistem Instruksional (PPSI). Sistem yang senantiasa mengarah kepada tercapainya tujuan yang spesifik, dapat diukur dan dirumuskan dalam bentuk tingkah laku siswa. ; Dipengaruhi psikologi tingkah laku dengan menekankan kepada stimulus respon (rangsang-jawab) dan latihan (drill).

\section{Kelebihan Kurikulum 1975}

Menekankan pada pendidikan yang lebih efektif dan efisien dalam hal daya dan waktu ; Menganut sistem yang senantiasa mengarah kepada tercapainya tujuan yang spesifik,dapat diukur dan dirumuskan dalam bentuk tingkah laku siswa

\section{Kelemahan Kurikulum 1975}

Guru dibuat sibuk menulis rincian apa yang akan dicapai dari setiap kegiatan pembelajaran.

Kurikulum $1984^{12}$

Kurikulum 1984 mengusung process skill approach. Meski mengutamakan pendekatan proses, tapi faktor tujuan tetap penting. Kurikulum ini juga sering disebut "Kurikulum 1975 yang disempurnakan". Posisi siswa ditempatkan sebagai subjek belajar. Dari mengamati sesuatu, mengelompokkan, mendiskusikan, hingga melaporkan. Model ini disebut Cara Belajar Siswa Aktif (CBSA) atau Student Active Leaming (SAL). Tokoh penting dibalik lahirnya Kurikulum 1984 adalah Profesor Dr. Conny R. Semiawan, Kepala Pusat Kurikulum Depdiknas periode 1980-1986 yang juga Rektor IKIP Jakarta — sekarang Universitas Negeri Jakarta - periode 1984-1992. Konsep CBSA yang elok secara teoritis dan bagus hasilnya di sekolah-sekolah yang diujicobakan, mengalami banyak deviasi dan reduksi saat diterapkan secara nasional. Sayangnya, banyak sekolah kurang mampu menafsirkan CBSA. Yang terlihat adalah suasana gaduh di ruang kelas lantaran siswa berdiskusi, di sana-sini ada tempelan gambar, dan yang menyolok guru tak lagi mengajar model berceramah. Penolakan CBSA bermunculan.

\section{Karakteristik Kurikulum 1984}

${ }^{12}$ http://www.musbir.blogspot.com/kurikulum-yang-pernah-berlaku-di.html. Diakses tanggal 16 April 
Mengusung process skill approach. Meski mengutamakan pendekatan proses, tapi faktor tujuan tetap penting. Kurikulum ini juga sering disebut "kurikulum1975 yang disempurnakan" ; CBSA merupakan suatu upaya dalam pembaharuan pendidikan dan pembelajaran pada saat itu. Pendekatannya menitikberatkan pada keaktifan siswa yang merupakan inti dari kegiatan belajar ; Dalam CBSA kegiatan belajarnya diwujudkan dalam berbagai bentuk kegiatan seperti mendengarkan, berdiskusi, membuat sesuatu, menulis laporan, memecahkan masalah, membentuk gagasan, menyusun rencana dan sebagainya ; Materi pelajaran dikemas dengan nenggunakan pendekatan spiral. Spiral adalah pendekatan yang digunakan dalam pengemasan bahan ajar berdasarkan kedalaman dan keluasan materi pelajaran. Semakin tinggi kelas dan jenjang sekolah, semakin dalam dan luas materi pelajaran yangdiberikan ; Menanamkan pengertian terlebih dahulu sebelum diberikan latihan. Konsepkonsep yang dipelajari siswa harus didasarkan kepada pengertian, baru kemudian diberikan latihan setelah mengerti. Untuk menunjang pengertian alat peraga sebagai media digunakan untuk membantu siswa memahami konsep yang dipelajarinya ; Materi disajikan berdasarkan tingkat kesiapan atau kematangan siswa. Pemberian materi pelajaran berdasarkan tingkat kematangan mental siswa dan penyajian pada jenjang sekolah dasar harus melalui pendekatan konkret, semikonkret, semiabstrak, dan abstrak dengan menggunakan pendekatan induktif dari contoh-contoh ke kesimpulan. Dari yang mudah menuju ke sukar dan dari sederhana menuju ke kompleks ; Menggunakan pendekatan keterampilan proses. Keterampilan proses adalah pendekatan belajar mengajar yang memberi tekanan kepada proses pembentukkan keterampilan memperoleh pengetahuan dan mengkomunikasikan perolehannya. Pendekatan keterampilan proses diupayakan dilakukan secara efektif dan efesien dalam mencapai tujuan pelajaran.

\section{Kelebihan kurikulum 1984 (CBSA)}

Pendekatan pembelajaran yang memberikan kesempatan kepada siswa untuk aktif terlibat secara fisik, mental, intlektual dan emosional dengan harapan siswa memperoleh pengalaman belajar secara maksimal, baik dalam ranah kognitif, afektip, maupun psikomotor.

\section{Kekurangan Kurikulum 1984 (CBSA)}

Posisi siswa ditempatkan sebagai subjek belajar ; Banyak sekolah kurang mampu menafsirkan CBSA, yang terlihat adalah suasana gaduh di ruang kelas lantaran siswa berdiskusi, di sana sini ada tempelan gambar, dan yang menyolok guru tak lagi mengajaar model berceramah.

Kurikulum 1994 dan Suplemen Kurikulum $1999^{13}$

${ }^{13}$ http://www.musbir.blogspot.com/kurikulum-yang-pernah-berlaku-di.html. Diakses tanggal 16 April 
Kurikulum 1994 bergulir lebih pada upaya memadukan kurikulum-kurikulum sebelumnya. "Jiwanya ingin mengkombinasikan antara Kurikulum 1975 dan Kurikulum 1984, antara pendekatan proses," kata Mudjito menjelaskan. Sayang, perpaduan tujuan dan proses belum berhasil. Kritik bertebaran, lantaran beban belajar siswa dinilai terlalu berat. Dari muatan nasional hingga lokal. Materi muatan lokal disesuaikan dengan kebutuhan daerah masing-masing, misalnya bahasa daerah kesenian, keterampilan daerah, dan lain-lain. Berbagai kepentingan kelompok-kelompok masyarakat juga mendesakkan agar isu-isu tertentu masuk dalam kurikulum. Walhasil, Kurikulum 1994 menjelma menjadi kurikulum super padat. Kejatuhan rezim Soeharto pada 1998, diikuti kehadiran Suplemen Kurikulum 1999. Tapi perubahannya lebih pada menambal sejumlah materi.

\section{Karakteristik kurikulum 1994}

Pembagian tahapan pelajaran di sekolah dengan sistem catur wulan; Pembelajaran di sekolah lebih menekankan materi pelajaran yang cukup padat (berorientasi kepada materi pelajaran/isi) ; Kurikulum 1994 bersifat populis, yaitu yang memberlakukan satu sistem kurikulum untuk semua siswa di seluruh Indonesia. Kurikulum ini bersifat kurikulum inti sehingga daerah yang khusus dapat mengembangkan pengajaran sendiri disesuaikan dengan lingkungan dan kebutuhan masyarakat sekitar ; Dalam pelaksanaan kegiatan, guru hendaknya memilih dan menggunakan strategi yang melibatkan siswa aktif dalam belajar, baik secara mental, fisik, dan sosial. Dalam mengaktifkan siswa guru dapat memberikan bentuk soal yang mengarah kepada jawaban konvergen, divergen (terbuka, dimungkinkan lebih dari satu jawaban) dan penyelidikan ; Dalam pengajaran suatu mata pelajaran hendaknya disesuaikan dengan kekhasan konsep/pokok bahasan dan perkembangan berpikir siswa, sehingga diharapkan akan terdapat keserasian antara pengajaran yang menekankan pada pemahaman konsep dan pengajaran yang menekankan keterampilan menyelesaikan soal dan pemecahan masalah.

\section{Kelebihan Kurikulum 1994}

Penggunaan strategi yang melibatkan siswa aktif dalam belajar, baik secara mental, fisik, dan social ; Pengajaran dari hal yang konkret ke hal yang abstrak, dari hal yang mudah ke hal yang sulit, dari hal yang sederhana ke hal yang kompleks.

\section{Kekurangan Kurikulum 1994}

Aspek yang di kedepankan dalam kurikulum 1994 terlalu padat ; Konsep pengajaran satu arah, dari guru ke murid ; Beban belajar siswa terlalu berat karena banyaknya mata pelajaran dan banyaknya materi/ substansi setiap mata pelajaran ; Materi pelajaran yang dianggap terlalu sukar karena kurang relevan dengan tingkat perkembangan berpikir siswa, dan kurang bermakna karena kurang terkait dengan aplikasi kehidupan sehari- 
hari.Pengulangan-pengulangan materi yang dianggap sulit perlu dilakukan untuk pemantapan pemahaman.

Kurikulum $2004^{14}$

Kurikulum Berbasis Kompetensi (KBK). Setiap pelajaran diurai berdasar kompetensi apakah yang mesti dicapai siswa. Sayangnya, kerancuan muncul bila dikaitkan dengan alat ukur kompetensi siswa, yakni ujian. Ujian akhir sekolah maupun nasional masih berupa soal pilihan ganda. Bila target kompetensi yang ingin dicapai, evaluasinya tentu lebih banyak pada praktik atau soal uraian yang mampu mengukur seberapa besar pemahaman dan kompetensi siswa. Meski baru diujicobakan, di sejumlah sekolah kota-kota di Pulau Jawa, dan kota besar di luar Pulau Jawa telah menerapkan KBK. Hasilnya tak memuaskan. Guru-guru pun tak paham betul apa sebenarnya kompetensi yang diinginkan pembuat kurikulum. (sumber: depdiknas.go.id).

\section{Karakteristik Kurikulum 2004}

Menekankan pada ketercapaian kompetensi siswa baik secara individual maupun klasikal; Berorientasi pada hasil belajar (learning outcomes) dan keberagaman ; Penyampaian dalam pembelajaran menggunakan pendekatan dan metode yang bervariasi ; Sumber belajar bukan hanya guru, tetapi juga sumber belajar lainnya yang memenuhi unsur edukatif ; Penilaian menekankan pada proses dan hasil belajar dalam upaya penguasaan atau pencapaian suatu kompetensi.

\section{Kelebihan Kurikulum 2004}

Dalam pembelajaran adanya komunikasi dua arah antara guru dan siswa ; Pembelajaran berpusat pada siswa ; Penggunaan pendekatan dan metode yang bervariasi ; Sumber belajar yang bervariasi.

\section{Kekurangan Kurikulum 2004}

Kurangnya sumber manusia yang potensial dalam menjabarkan KBK dengan kata lain masih rendahnya kualitas sorang guru, karena dalam KBK seorang guru dituntut untuk lebih kreatif dalam menjalankan pendidikan.

KTSP $2006^{15}$

Awal 2006 ujicoba KBK dihentikan. Muncullah Kurikulum Tingkat Satuan Pendidikan. Pelajaran KTSP masih tersendat. Tinjauan dari segi isi dan proses pencapaian

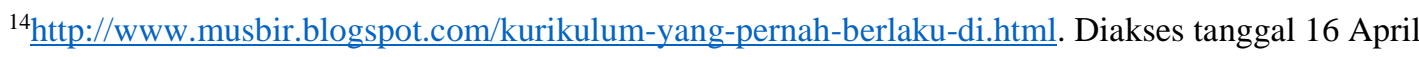

\footnotetext{
${ }^{15}$ http://www.musbir.blogspot.com/kurikulum-yang-pernah-berlaku-di.html. Diakses tanggal 16 April
} 
target kompetensi pelajaran oleh siswa hingga teknis evaluasi tidaklah banyak perbedaan dengan Kurikulum 2004. Perbedaan yang paling menonjol adalah guru lebih diberikan kebebasan untuk merencanakan pembelajaran sesuai dengan lingkungan dan kondisi siswa serta kondisi sekolah berada. Hal ini disebabkan kerangka dasar (KD), standar kompetensi lulusan (SKL), standar kompetensi dan kompetensi dasar (SKKD) setiap mata pelajaran untuk setiap satuan pendidikan telah ditetapkan oleh Departemen Pendidikan Nasional. Jadi pengambangan perangkat pembelajaran, seperti silabus dan sistem penilaian merupakan kewenangan satuan pendidikan (sekolah) dibawah koordinasi dan supervisi pemerintah Kabupaten/Kota.

\section{Karakteristik KTSP}

Menekankan pada ketercapaian kompetensi siswa, baik secara individual, maupun klasikal ; Berorientasi pada hasil belajar (learning out comes) dan keberagaman ; Penyampaian dalam pembelajaran menggunakan pendekatan dan metode yang bervariasi ; Sumber belajar bukan hanya guru, tetapi juga sumber belajar lainnya yang memenuhi unsure edukatif ; Penilaian menekankan pada proses dan hasil belajar dalam upaya penguasaan atau pencapaian suatu kompetensi.

\section{Kelebihan KTSP}

Dalam pembelajaran adanya komunikasi dua arah antara guru dan siswa ; Pembelajaran berpusat pada siswa ; Penggunaan pendekatan dan metode yang bervariasi ; Sumber belajar yang bervariasi ; Seorang guru benar-benar digerakkan menjadi manusia yang professional yang menuntut kekereatifitasan.

\section{Kekurangan KTSP}

Minimnya sosialisasi dan kesiapan sarana dan prasarana pendukung pendidikan dan terutama sekali kesiapan guru dan sekolah untuk menyusun dan mengembangkan kurikulum sendiri.

Kurikulum $2013^{16}$

Ada empat aspek yang harus diberi perhatian khusus dalam rencana implementasi dan keterlaksanaan kurikulum 2013.Kompetensi guru dalam pemahaman substansi bahan ajar, yang menyangkut metodologi pembelajaran, yang nilainya pada pelaksanaan uji kompetensi guru (UKG) baru mencapai rata-rata 44,46 ; Kompetensi akademik di mana guru harus menguasai metode penyampaian ilmu pengetahuan kepada siswa ; Kompetensi sosial yang harus dimiliki guru agar tidak bertindak asocial kepada siswa dan teman sejawat lainnya ;

${ }^{16}$ http://www.musbir.blogspot.com/kurikulum-yang-pernah-berlaku-di.html. Diakses tanggal 16 April
} 
Kompetensi manajerial atau kepemimpinan karena guru sebagai seorang yang akan digugu dan ditiru siswa.

Kesiapan guru sangat urgen dalam pelaksanaan kurikulum ini. Kesiapan guru ini akan berdampak pada kegiatan guru dalam mendorong mampu ;ebih baik dalam melakukan observasi, bertanya, bernalar, dan mengkomunikasikan apa yang telah mereka peroleh setelah menerima materi pembelajaran.

\section{Keunggulan kurikulum 2013}

Siswa lebih dituntut untuk aktif, kreatif dan inovatif dalam setiap pemecahan masalah yang mereka hadapi di sekolah ; Adanya penilaian dari semua aspek. Penentuan nilai bagi siswa bukan hanya didapat dari nilai ujian saja tetapi juga didapat dari nilai kesopanan, religi, praktek, sikap dan lain-lain ; Munculnya pendidikan karakter dan pendidikan budi pekerti yang telah diintegrasikan ke dalam semua program studi ; Adanya kompetensi yang sesuai dengan tuntutan fungsi dan tujuan pendidikan nasional ; Kompetensi yang dimaksud menggambarkan secara holistic domain sikap, ketrampilan, dan pengetahuan ; Banyak kompetensi yang dibutuhkan sesuai perkembangan seperti pendidikan karakter, metodologi pembelajaran aktif, keseimbangan soft skills dan hard skills, kewirausahaan ; Hal yang paling menarik dari kurikulum 2013 ini adalah sangat tanggap terhadap fenomena dan perubahan sosial. Hal ini mulai dari perubahan sosial yang terjadi pada tingkat lokal, nasional, maupun global ; Standar penilaian mengarahkan kepada penilaian berbasis kompetensi seperti sikap, ketrampilan dan pengetahuan secara proporsional ; Mengharuskan adanya remediasi secara berkala ; Sifat pembelajaran sangat kontekstual ; Meningkatkan motivasi mengajar dengan meningkatkan kompetensi profesi, pedagogi, sosial dan personal ; Ada rambu-rambu yang jelas bagi guru dalam melaksanakan proses pembelajaran (buku induk) ; Guru berperan sebagai fasilitator ; Diharapkan kreatifitas guru akan semakin meningkat ; Efisiensi dalam manajemen sekolah contohnya dalam pengadaan buku, dimana buku sudah disiapkan dari pusat ; Sekolah dapat memperoleh pendampingan dari pusat dan memperoleh koordinasi dan supervise dari daerah ; Pembelajaran berpusat pada siswa dan kontekstual dengan metode pembelajaran yang lebih bervariasi ; Penilaian meliputi aspek kognitif, afektif, psikomotorik sesuai proporsi ; Ekstrakurikuler wajib Pramuka meningkatkan karakter siswa terutama dalam kedisiplinan, kerjasama, saling menghargai, cinta tanah air dan lain-lain.

\section{Kelemahan kurikulum 2013}

Guru banyak salah kaprah, karena beranggapan dengan kurikulum 2013 guru tidak perlu menjelaskan materi kepada siswa di kelas, padahal banyak mata pelajaran yang harus tetap ada penjelasan dari guru ; Banyak sekali guru-guru yang belum siap secara mental dengan kurikulum 2013 ini, karena kurikulum ini menuntut guru lebih kreatif, pada kenyataannya sangat sedikit para guru yang seperti itu, sehingga membutuhkan waktu yang panjang agar bisa membuka cakrawala berfikir guru, dan salah satunya dengan pelatihanpelatihan dan pendidikan agar merubah paradigm guru sebagai pemberi materi menjadi guru yang dapat memotivasi siswa agar kreatif ; Kurangnya pemahaman guru dengan konsep pendekatan scientific ; Kurangnya ketrampilan guru merancang RPP ; Guru tidak banyak 
yang menguasai penilaian autentik; Tugas menganalisis SKL, KI, KD buku siswa dan buku guru belum sepenuhnya dikerjakan oleh guru, dan banyaknya guru yang hanya menjadi plagiat dalam kasus ini ; Tidak pernahnya guru dilibatkan langsung dalam proses pengembangan kurikulum 2013, karena pemerintah cenderung melihat guru dan siswa mempunyai kapasitas yang sama ; Tidak adanya keseimbangan antara orientasi proses pembelajaran dan hasil dalam kurikulum 2013 karena UN masih menjadi factor penghambat ; Terlalu banyak materi yang harus dikuasai siswa sehingga tidak setiap materi bisa tersampaikan dengan baik, belum lagi persoalan guru yang kurang berdedikasi terhadap mata pelajaran yang dia ampu ; Beban belajar siswa dan guru terlalu berat, sehingga waktu belajar di sekolah terlalu lama ; Timbulnya kecemasan khususnya guru mata pelajaran yang dihapus yaitu KPPI, IPA dan Kewirausahaan dan terancam sertifikasiya dicabut ; Sebagian besar guru masih terbiasa menggunakan cara konvensional ; Penguasaan teknologi dan informasi untuk pembelajaran masih terbatas ; Guru tidak tiap dengan perubahan ; Kurangnya kekmampaun guru dalam proses penilaian sikap, ketrampilan dan pengetahuan secara holistic ; Kreatifitas dalam pengembangan silabus berkurang ; Otonomi sekolah dalam pengembangan kurikulum berkurang ; Sekolah tidak mandiri dalam menyikapi kurikulum ; Tingkat keaktifan siswa belum merata ; KBM umumnya saat ini mash konvensional ; Belum semua guru memahami sistem penilaian sikap dan ketrampilan ; Menambah beban kerja guru ; Citra sekolah dan guru akan menurun jika tidak berhasil menjalankan kurikulum 2013 ; Pramuka menjadi beban bagi siswa yang tidak menyukai Pramuka, sehingga ada unsur keterpaksaan.

\section{Hubungan Sejarah Kurikulum Nasional IndonesiaTerhadap Pengembangan Kurikulum PAK Masa Kini}

Hadirnya Program Studi Pendidikan Agama Kristen (dibaca PAK) di berbagai sekolah teologi/AK di negeri tercinta ini setidaknya mempengaruhi laju perkembangan kurikulum pendidikan agama Kristen itu sendiri. Masing-masing sekolah dengan kekhasan yang dimilikinya dan didukung oleh kebijakan pemerintah agar sekolah-sekolah teologi/AK itu dapat terus berkembang, maka sekolah-sekolah teologi/AK terus berbenah diri guna menghadirkan kurikulum-kurikulum yang terbaik untuk digunakan di dalam membangun insan manusia terbaik di negeri tercinta ini, khususnya orang-orang Kristen. Seorang pengajar PAK dari STT HKBP Pematang Siantar yang bernama albert Saragih mengatakan:

Pendidikan Agama Kristen (selanjutnya disingkat PAK) pada dasawarsa belakangan ini semakin terkenal, bahkan secara akademis bertambah eksis di Indonesia. Hal itu terbukti dengan semakin berperannya para tokoh PAK terlibat beberapakali dalam merumuskan pembaharuan kurikulum nasional. Di sisi lain, secara akademis pengembangan program Prodi PAK di Perguruan Tinggi Teologi Agama Kristen (PTTAK) bukan lagi hanya bertumpu pada S1 Negeri maupun swasta, tapi puluhan STT sudah membuka program pascasarjana prodi PAK S2 (Magister Pendidikan Kristen) maupun program doktoral (S3) konsentrasi PAK. Hal ini satu sisi tentu menggembirakan, karena dengan demikian kebutuhan dosen STT untuk mengajar program S1, sesuai UU guru dan dosen, harus S2 berijazah negara(terakreditas), dan untuk yang mengajar Pascasarjana harus Doktor berijazah negara (terakreditas). Juga dengan ketersediaan SDM itu memberi peluang kepada STT untuk mendapatkan dosen tetap sehingga memberi dampak kepada terbukanya 3 kesempatan , pertama, untuk terakreditasi di BNPT, sama seperti perguruan tinggi lainnya; kedua, para dosen mendapatkan jabatan fungsional; dan ketiga, para dosen mendapatkan 
tunjangan fungsional. Sungguh suatu yang harus disyukuri. Pada pihak lain, dengan semakin banyak PTTAK membuka dan meluluskan para Magister Pendidikan Kristen dan Doktor Teologi pada konsentrasi PAK, terlepas dari plus-minusnya, saya mencermati ada tanggung jawab besar yang harus diemban untuk memajukan PAK di Indonesia; yakni melakukan pengembangan PAK itu sendiri sehingga semakin membumi. ${ }^{17}$

Dari pernyataan tersebut diatas dapatlah kita pahami bahwa perkembangan yang dialami oleh sekolah teologi/AK begitu menggembirakan dan oleh sebab itu sekolah-sekolah teologi/AK harus terus berkontribusi aktif dan nyata memberikan sumbangsihnya bagi pendidikan dan kurikulum pendidikan Kristen ditengah-tengah umat di negeri tercinta ini.

Saat ini pemerintah melalui Kementerian Pendidikan \& Kebudayaan RI telah menerapkan kurikulum yang baru, yakni K13 sebagai kurikulum yang resmi berlaku di Indonesia, dimana pelajaran Agama masuk dalam pelajaran Agama dan Budi Pekerti, disinilah kesigapan para calon guru dan guru agama Kristen serta semua perangkat yang ada di dalamnya terus meningkatkan kinerjanya bagi pembenahan kurikulum yang memperkenalkan semua siswa didik kepada Juruselamatnya masing-masing.

\section{Kurikulum Sekolah Kristen}

Kurikulum yang merupakan nafas dari pendidikan itu harus menjadi perhatian serius para pemerhati pendidikan Kristen itu sendiri. Mencatat apa yang dikatakan oleh Albert Saragih dalam tulisannya bahwa kurikulum yang berlaku di sekolah Kristen haruslah seperti berikut ini:

Pendidikan merupakan usaha manusia dalam mempelajari dan mendapatkan pengetahuan. Alkitab, adalah Firman TUHAN yang memiliki otoritas untuk kehidupan hidup Kristen. Orang percaya mengungkapkan segala pujian dan rasa syukur atas segala perbuatanNya. Ilmu pengetahuan adalah buah dari hikmat dan akal budi yang Tuhan berikan, sehingga manusia dapat mengembangkan dirinya, mengelola alam sekitarnya (Kej 1:28) Sehubungan dengan itu, menurut Eva Frederika dkk dari Universitas Pelita Harapan, Tangerang, pengetahuan seharusnya dipergunakan untuk mengagungkan kebesaran Tuhan bukankah manusia yang adalah ciptaanNya. Landasan pelaksanaan pendidikan terdapat dalam tiga perintah Alkitab, yaitu Mandat Penciptaan, Amanat Agung, dan Perintah Agung Dalam Mandat Agung, Tuhan memberikan perintah penciptaan kepada manusia untuk menjaga dan melayani (Kej 1:28; 2:15; Maz 8:6-8). Sekolah harus memberikan pengajaran kepada murid untuk memiliki kemampuan dalam menjaga dunia ini, melalui materi kognitif dan keterampilan Kejatuhan manusia jatuh ke dalam dosa, membuat Yesus turun ke dalam dunia menyelamatkan, dan memulihkan agar setiap orang yang percaya kepadaNya tidak binasa melainkan memperoleh hidup yang kekal (Joh 14:6). Oleh karena itu, sekolah harus dapat menantang murid untuk menyerahkan hidup kepada Yesus Kristus dan memahami implikasinya, artinya mengajarkan murid-murid untuk memakai kacamata Firman dalam menghadapi masalah-masalah pribadi maupun masyarakat, dengan mengembangkan karakter dan kecerdasan murid untuk bertindak

${ }^{17}$ www://https://albetsaragih.blogspot.co.id/2017/03/pengembangan-pak.html. Diakses tanggal 20 April 
berlandaskan prinsip Alkitabiah yang diajarkan Yesus Kristus Setelah dosa kita ditebus oleh darah Yesus Kristus, kita harus hidup di dalam perintah agungNya untuk mengasihi Tuhan Allah dengan sepenuh hati dan sesama manusia seperti diri sendiri (Luk 10:27). Dalam hal ini, guru harus mengajarkan murid mempelajari visi kekristenan dalam kehidupan dan membantu murid membukakan karunia mereka dengan saling melayani satu sama lain, berbagi kebahagiaan, dan membantu menanggung beban. Sehubungan dengan tiga perintah Alkitab tersebut, maka tugas Pendidikan Agama Kristen secara keseluruhan memiliki dua dimensi, yaitu tugas penyembuhan dan tugas perkembangan ${ }^{18[8]}$. Dalam tugas penyembuhan, sekolah harus dapat menjadi pengalaman yang menyembuhkan bagi para murid maupun para guru. Para guru harus mempunyai dua mata dalam menjalankan tugasnya di sekolah, yaitu satu mata untuk mendidik dan memperhatikan para muridnya, dan satu mata berikutnya untuk menangis bersama para muridnya bila mereka terluka di luar sekolah agar mereka tahu bahwa sekolah adalah tempat yang aman untuk berlindung. ${ }^{19}$

Pertanyaan yang ingin diajukan saat ini adalah bahwa hubungan sejarah perkembangan kurikulum pendidikan nasional Indonesia terhadap perkembangan kurikulum PAK masa kini sudah berjalan dengan baik, walaupun masih banyak yang harus diperhatikan sebagai perbaikan sini sana demi kemajuan penddidikan Kristen itu sendiri. Untuk itu diperlukan kerja keras dan usaha dari pemerhati pendidikan Kristen itu sendiri sehingga kedepan pengembangan kurikulum pendidikan agama Kristen semakin kreatif, inovatif serta mumpuni dan berbobot. 


\section{Kesimpulan}

Guru dan calon guru PAK yang dididik di bangku-bangku sekolah teologi/AK sebagai tenaga-tenaga yang terampil adalah insan pendidikan yang merupakan garda terdepan bagi tercapainya tujuan dari amanat agung Tuhan Yesus dalam Matius 28;18-20, sehingga para pendidik ini siap berinovasi dalam menjalankan tugasnya untuk mengembangkan kurikulum pendidikan agama Kristen dan budi pekerti.

Dari sejarah perkembangan kurikulum nasional kita mengetahui bahwa keinginan pemerintah adalah menghadirkan model kurikulum yang menjawab kebutuhan masyarakat sesuai dengan konteks masyarakat Indonesia, dan hadirnya kurikulum itu dalam pelaksanan pembelajaran PAK sangat berhubungan erat. Ini membuat sekolah-sekolah teologi/AK sebagai tempat penggodokan calon guru-guru PAK terus berinovasi memikirkan kurikulum terbaik untuk digunakan kepada semua orang Kristen di bumi pertiwi ini.

Dari sini kita melihat bahwa pendidikan Kristen harus ditangani dengan baik dan bertanggung jawab agar apa yang menjadi keinginan Tuhan Yesus agar semua bangsa menjadi murid-Nya tercapai dan terwujud. 


\section{DAFTAR PUSTAKA}

Hamalik Oemar,Dasar-Dasar Pengembangan Kurikulum Bandung: Penerbit PT Remaja Rosdakarya, 2009

Hilda Taba. Curriculum development; theory and practice (New York : Harcourt, Brace \& World, 1962), 58

http://www.artikelsiana.com/pengertian-kurikulum-fungsi-komponen. Diakses tanggal 10 April 2016

International Council of Religious Education in Journal Religious Education The official journal of the Religious Education Association. (Volume 2, 2006), 51

http://www.musbir.blogspot.com/kurikulum-yang-pernah-berlaku-di.html. Diakses tanggal 16 April 2016.

http://www.musbir.blogspot.com/kurikulum-yang-pernah-berlaku-di.html. Diakses tanggal 16 April 2016

http://www.musbir.blogspot.com/kurikulum-yang-pernah-berlaku-di.html. Diakses tanggal 16 April 2016

http://www.musbir.blogspot.com/kurikulum-yang-pernah-berlaku-di.html. Diakses tanggal 16 April 2016

http://www.musbir.blogspot.com/kurikulum-yang-pernah-berlaku-di.html. Diakses tanggal 16 April 2016

http://www.musbir.blogspot.com/kurikulum-yang-pernah-berlaku-di.html. Diakses tanggal 16 April 2016

http://www.musbir.blogspot.com/kurikulum-yang-pernah-berlaku-di.html. Diakses tanggal 16 April 2016

http://www.musbir.blogspot.com/kurikulum-yang-pernah-berlaku-di.html. Diakses tanggal 16 April 2016

Majid Abdul, Perencanaan Pembelajaran, Mengembangakan Standar Dan Kompetenssi

GuruBandung: Penerbit PT Remaja Rosdakarya, 2011

www://https://albetsaragih.blogspot.co.id/2017/03/pengembangan-pak.html. Diakses tanggal 20 April 2016

www://https://albetsaragih.blogspot.co.id/2017/03/pengembangan-pak.html. Diakses tanggal 20 April 2016

Yudha Nata Saputra, Diktat Pengembangan Kurikulum PAK, Semester VII STT Cipanas

(Cipanas-Jawa Barat, 2012). 5 